Bangladesh J. Plant Taxon. 28(1): 217-231, 2021 (June)

(C) 2021 Bangladesh Association of Plant Taxonomists

https://doi.org/10.3329/bjpt.v28i1.54218

\title{
EPIDERMAL AND ANATOMICAL STUDIES ON CHRYSOPHYLLUM L. (SAPOTACEAE) SPECIES OF SOUTH-EASTERN NIGERIA
}

\author{
Chimezie EkeKe $^{1}{ }^{*}$, Joseph Ariwaodo ${ }^{2}$ and Solomon Odeyemi ${ }^{3}$ \\ Department of Plant Science and Biotechnology, Faculty of Sciences, \\ University of Port Harcourt, P.M.B. 5323, Port Harcourt, Rivers State, Nigeria
}

Keywords: Chrysophyllum; Epidermis; Anatomy; Leaf; Stem; Nigeria.

\begin{abstract}
The epidermal characters of leaves and anatomical characters of petioles and young stems of some members of the genus Chrysophyllum, viz. C. albidum, C. perpulchrum, $C$. cainito, and $C$. delevoyi were analyzed to determine their diagnostic features. Paracytic stomata, crystal sand, prismatic crystals, secretory canals occurred in all the species. All the species are hypostomatic except $C$. perpulchrum. The midribs of all species have an open semi-circular vascular system except in $C$. cainito with a closed system. Midrib and petiole of $C$. albidum and $C$. cainito have non-glandular T-shaped trichomes. Accessory bundles are only seen in the petioles of $C$. delevoyi, and in the midribs of $C$. albidum and C. cainito. The midrib and petiole of $C$. delevoyi and $C$. albidum have a central bundle. Laticifers, prismatic and sand crystals occur mainly in the cortical cells, pith cells, xylem, phloem, and mesophyll. Lamina of all species studied showed uniseriate epidermis except $C$. cainito which has two layers of the adaxial epidermis. The stomatal index, the ratio of the spongy to palisade mesophyll thickness, the ratio of cortex thickness, outline, number, and arrangement of the vascular bundles in the midrib, petiole, and young stem differ and are valuable diagnostic features in Chrysophyllum.
\end{abstract}

\section{Introduction}

Sapotaceae is one of the large families of flowering plant and comprises about 60 genera and 1300 species (Pennington, 1991; Govaerts et al., 2001), 60-70 species of which are native to tropical and subtropical regions of the world, especially America, West Africa, and Australia (Shailajan and Gurjar, 2014). In Africa, there are approximately 51 species under 23 genera (Hutchinson and Dalziel, 1954). 13 species are reported from West Africa and seven species from Nigeria (Hutchinson and Dalziel, 1954; Keay, 1989).

Several authors have reported that the members of this family are mainly lowland species, have wide morphological variations, and provide essential resources to native fauna and humans (Prasawang and Srinual, 2020; Felippi et al., 2008; Gomes et al., 2008; Reis et al., 2013). Members of this genus have many health benefits including antidiabetes, anti-inflammation, anticancer, antioxidant, antimicrobial, and rheumatoid arthritis properties (Koffi et al., 2009; Mallikarjun et al., 2011; Meira et al., 2014; Li et al., 2015; Mao et al., 2015; Hegde et al., 2016; Ningsih et al., 2016; Doan et al., 2018; George et al., 2018), cultural, and ethnobotanical uses (Inyama et al., 2016; Parker et al., 2010; Das et al., 2010).

The phylogenetic relationship of Sapotaceae including Chrysophyllum and other genera (Petersen et al., 2012; Swenson et al., 2013; Faria et al., 2017; Swenson et al., 2018; Borg et al., 2019), and anatomical features of this family (Metcalfe and Chalk, 1972) and other genera viz.

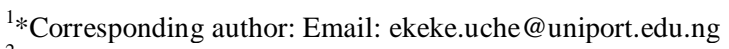

${ }^{2}$ Forestry Research Institute of Nigeria, Onne sub-station, Rivers State, Nigeria. Email: joseph.ariwaodo@yahoo.com

${ }^{3}$ Forestry Research Institute of Nigeria, Umuahia sub-station, Abia State, Nigeria. Email: toyes618@gmail.com
} 
Diploon Cronquist (Lima et al., 2019), Monotheca A. DC. (Ehsan et al., 2019), and Chrysophyllum (Inyama et al., 2016; Prasawang and Srinual, 2020) have been reported. Despite these information, the identification of Chrysophyllum is weak and problematic (Prasawang and Srinual, 2020), because the available identification keys are based on leaf and floral characteristics (Chayamarit, 2014). The floral parts of the species are not readily available and most of the species have close morphological resemblance (Chayamaritk, 2014). Also, the close morphological similarities of the three species of Chrysophyllum, viz. C. cainito L., C. albidum G. Don and C. subnudum Baker have made some scholars to consider $C$. subnudum as a variety of $C$. albidum (Prasawang and Srinual, 2020).

In trying to resolve this problem among Nigerian species, Inyama et al. (2016) have worked on some members of this genus (C. cainito, $C$. albidum and $C$. subnudum) and have reported that the species could be differentiated based on the anatomical features of the leaf and petiole. Also, Metcalfe and Chalk (1972), Araújo et al. (2010), and Almeida-Jr et al. (2012) have described the anatomy of the family Sapotaceae including Chrysophyllum and other genera. In spite of these studies, the anatomy of $C$. delevoyi De Wild. and C. perpulchrum Mildbr. ex Hutch. \& Dalziel are yet to be known.

Considering the morphological similarities among Chrysophyllum, the objectives of this work were to examine the epidermal characteristics, petiole, midrib, and young stem anatomy, occurrence and distribution of laticifers and idioblasts in C. albidum, C. cainito, C. delevoyi and $C$. perpulchrum to determine and provide additional diagnostic information on this genus from Nigeria.

\section{Materials and Methods}

\section{Plant Materials}

Plant samples of four species of Chrysophyllum were collected from live tree growing in Forestry Research Institute of Nigeria (FRIN) sub-stations (Umuahia, Abia State, and Calabar, Cross Rivers State). The plants were authenticated and voucher specimens were deposited in the University of Port Harcourt Herbarium, Nigeria (Table 1).

Table 1. List of Chrysophyllum species studied.

\begin{tabular}{|c|c|c|c|c|c|}
\hline $\mathrm{S} / \mathrm{N}$ & species Name & $\begin{array}{l}\text { Date of } \\
\text { collection }\end{array}$ & $\begin{array}{l}\text { Herbarium } \\
\text { number }\end{array}$ & $\begin{array}{l}\text { Name(s) of } \\
\text { collector }\end{array}$ & Locality \\
\hline 1 & C. delevoyi De Wild. & $29 / 07 / 2020$ & UPH/V/1463 & $\begin{array}{l}\text { Odeyemi \& } \\
\text { Ariwaodo, J }\end{array}$ & $\begin{array}{l}\text { FRIN sub-station, } \\
\text { Umuahia, Abia State, } \\
\text { Nigeria }\end{array}$ \\
\hline 2 & C. cainito $\mathrm{L}$. & $29 / 07 / 2020$ & UPH/V/1462 & $\begin{array}{l}\text { Odeyemi, } \\
\text { Solomon }\end{array}$ & $\begin{array}{l}\text { FRIN sub-station, } \\
\text { Umuahia, Abia State, } \\
\text { Nigeria }\end{array}$ \\
\hline 3 & C. albidum G. Don & $29 / 07 / 2020$ & UPH/V/1461 & Ekeke \& Ogazie & $\begin{array}{l}\text { FRIN sub-station, } \\
\text { Umuahia, Abia State, } \\
\text { Nigeria }\end{array}$ \\
\hline 4 & $\begin{array}{l}\text { C. perpulchrum Mildbr. } \\
\text { ex Hutch. \& Dalziel }\end{array}$ & 03/08/2020 & UPH/V/1464 & $\begin{array}{l}\text { Ogah, E. \& } \\
\text { Ariwaodo, J. }\end{array}$ & $\begin{array}{l}\text { FRIN sub-station, Calabar, } \\
\text { Cross Rivers State. }\end{array}$ \\
\hline
\end{tabular}




\section{Microscopic analysis}

Fresh leaves, petioles, and young stems were harvested and fixed in FAA (1:1:3) of formalin $(40 \%)$, acetic acid (30\%), and ethanol (70\%). Fixation, embedding, sectioning, epidermal mechanical scraping, and staining were done according to the procedures of Metcalfe and Chalk (1979) and Ekeke and Agogbua (2019) with suitable modification. The leaf blade and distal parts of the petiole were hand sectioned and stained in $1 \%$ Safranin O and counter in 1\% Alcian blue. The slides were then mounted in glycerogelatin and sealed with transparent nail polish (Kraus and Arduin, 1997). The vascular bundle arrangement in the petiole and midrib were classified according to Howard (1979). Fifty good slides were observed under research microscope and clear microphotographs of fine sections taken using a trinocular research microscope (T340B) fitted with an Amscope digital camera. The images were processed using the Analysis Document Software imaging system. The mean size and standard deviation of the plant cell sizes were calculated using Microsoft Excel 2010.

\section{Results and Discussion}

The results of the study on epidermal characteristics, leaf, and stem anatomical features of the four species of Chrysophyllum studied are presented in Figs 1-13. Generally, the species studied contain laticiferous cells, and prismatic crystals in their cortex, pith, and vascular bundles (mainly xylem tissues).

\section{Chrysophyllum delevoyi}

Epidermis: Leaf hypostomatic with a stomatal index of 9.09. The stomata on the abaxial epidermis are mainly paracytic but rarely anisocytic, tetracytic, and with abnormalities (poorly developed stomata, and contiguous stomata) (Fig. 1A, B and C). The abaxial surface is hairy with unicellular non-glandular hairs while the adaxial epidermis is glabrous. Both adaxial and abaxial epidermal cells are polygonal to irregular in shape, and anticlinal walls are sinus or wavy (Fig. 1D).

Midrib: The midrib has a circular outline, and the adaxial cuticle is convexly raised to form furrows on both arms of the leaf blade (Figs $3 \mathrm{~A}$ and 4). Parenchymatous cortex, pith, and xylem tissues contain calcium oxalate (prismatic crystals), tanniferous cells (Fig. 3B), and crushed parenchyma in the cortex (Fig. 3C). The vascular bundles are arranged in a $3 / 4$ circular system (crescent) consisting of adaxial and central (modullary) plates, and two interspersed phloem tissues (Figs 3A and 4A) surrounded by patches of fiber (2-4-layered thick) (Fig. 3b and C). The adaxial cortex has 9-11 layers of cells (15-18 $\mu \mathrm{m}$ thick), while the abaxial cortex is 8-12-layered (23-31 $\mu \mathrm{m}$ thick). The ratio of the thickness (abaxial/adaxial) is 1.72 (Table 3).

Petiole: Transverse section (TS) of the petiole has a circular outline with a V-shaped adaxial cuticle (Figs 5 and 12A). The adaxial cortex has 18-22 layers (62-115 $\mu$ m thick), and the adaxial cortex has 20-21 layers (113-138 $\mu \mathrm{m}$ thick) of cells. The ratio of the abaxial to abaxial parenchymatous cortex thickness is 1.34 (Table 3 ). The vascular bundles formed $3 / 4$ circular system with two rib traces, adaxial and central (modullary) bundle plates (Fig. 5); surrounded by patches of fibers sclerenchymatous fiber and vessels in radial multiples of 2-8 cells or partly in tangential pairs, and rays 2-3 cell-thick (Fig. 12D). Calcium oxalate (prismatic crystals and crystal sand), secretory canals, and tanniferous cells are observed in the parenchymatous cortex (Fig. 12B and C).

Young stem: The cortex of $C$. delevoyi has 10-14 layers of cells (20-32 $\mu$ m thick) while the pith is $189-214 \mu \mathrm{m}$ thick. The ratio of the thickness of the pith to the cortex is 8.13 (Table 3). 
Vessels are solitary or in pairs, and rays 1-2-celled thick with patches of fiber outwardly and crushed parenchyma in the cortex (Fig. 13A-C).

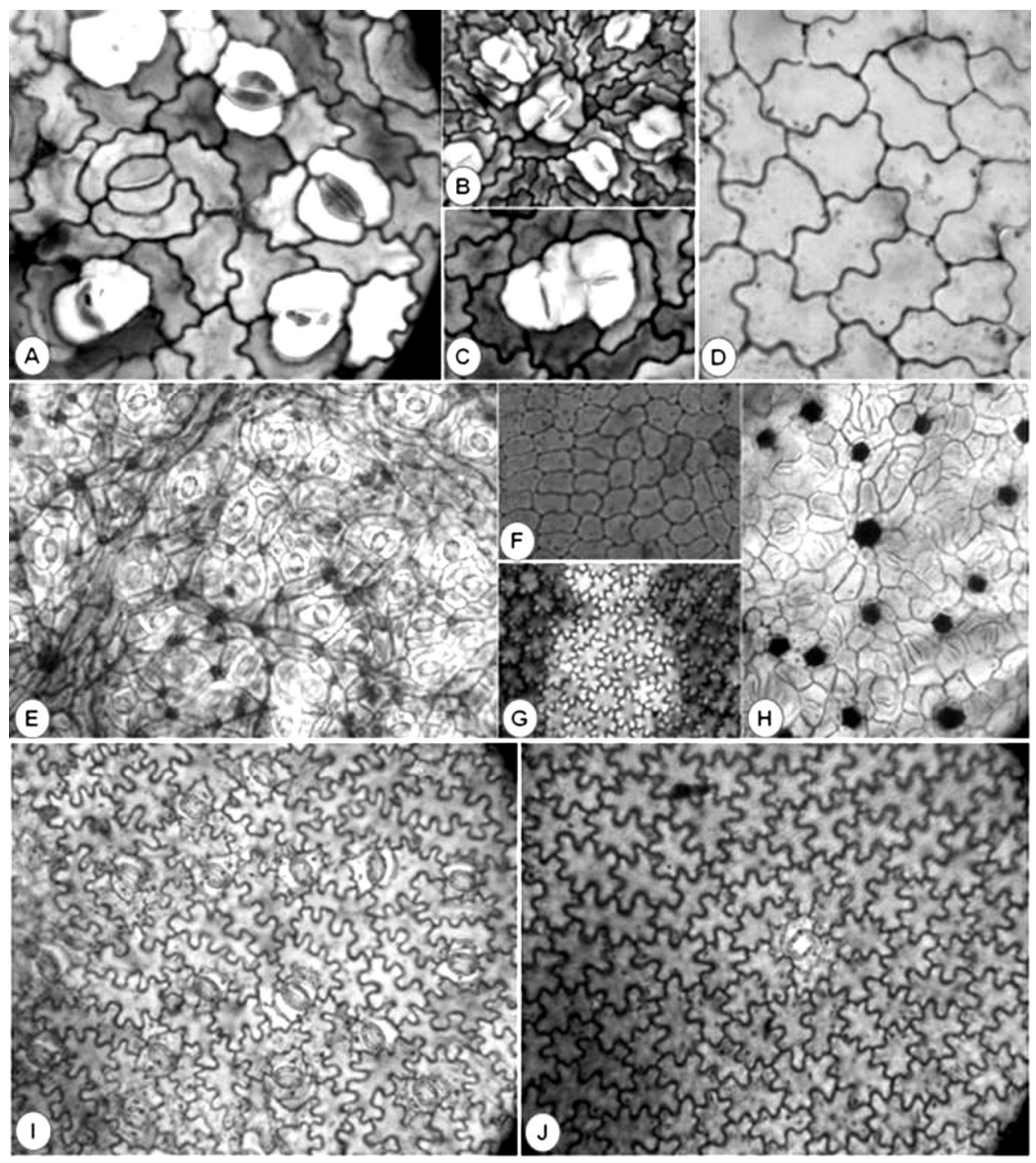

Fig. 1. Epidermal peels of the Chrysophyllum species studied. A-D = C. delevoyi, abaxial (A-C), adaxial (D); $\mathrm{EF}=C$. albidum, abaxial $(\mathrm{E})$, adaxial $(\mathrm{F}) ; \mathrm{GH}=C$. cainito, adaxial $(\mathrm{G})$, abaxial $(\mathrm{H}) ; \mathrm{IJ}=C$. perpulchrum (I) abaxial, adaxial (J).

\section{C. albidum}

Epidermis: Leaf hypostomatic with a stomatal index of 23.8. The stomata on the abaxial epidermis are mainly paracytic but rarely tetracytic (Fig. 1E and F). The abaxial surface is hairy with $\mathrm{T}$-shaped non-glandular trichomes while the adaxial epidermis is glabrous. Both adaxial and abaxial epidermal cells are polygonal to irregular in shape, with sinus or wavy anticlinal walls. 
Lamina: The lamina has uniseriate abaxial and adaxial epidermis. The mesophyll is characterized by 2 layers of palisade parenchyma (11-12 $\mu \mathrm{m}$ thick), and 4-6 layers of spongy parenchyma (20-23 $\mu \mathrm{m}$ thick). The palisade and spongy mesophylls contain tanniferous cells. The palisade tissue consists of periclinal elongated cells arranged in rows while the spongy parenchyma appeared less regular with large intercellular spaces (Fig. 2B). The vascular bundles are embedded mainly in the spongy mesophylls extending to the adaxial epidermis and the ratio of the spongy to palisade mesophyll thickness (S/P) is 1.52 (Table 2).

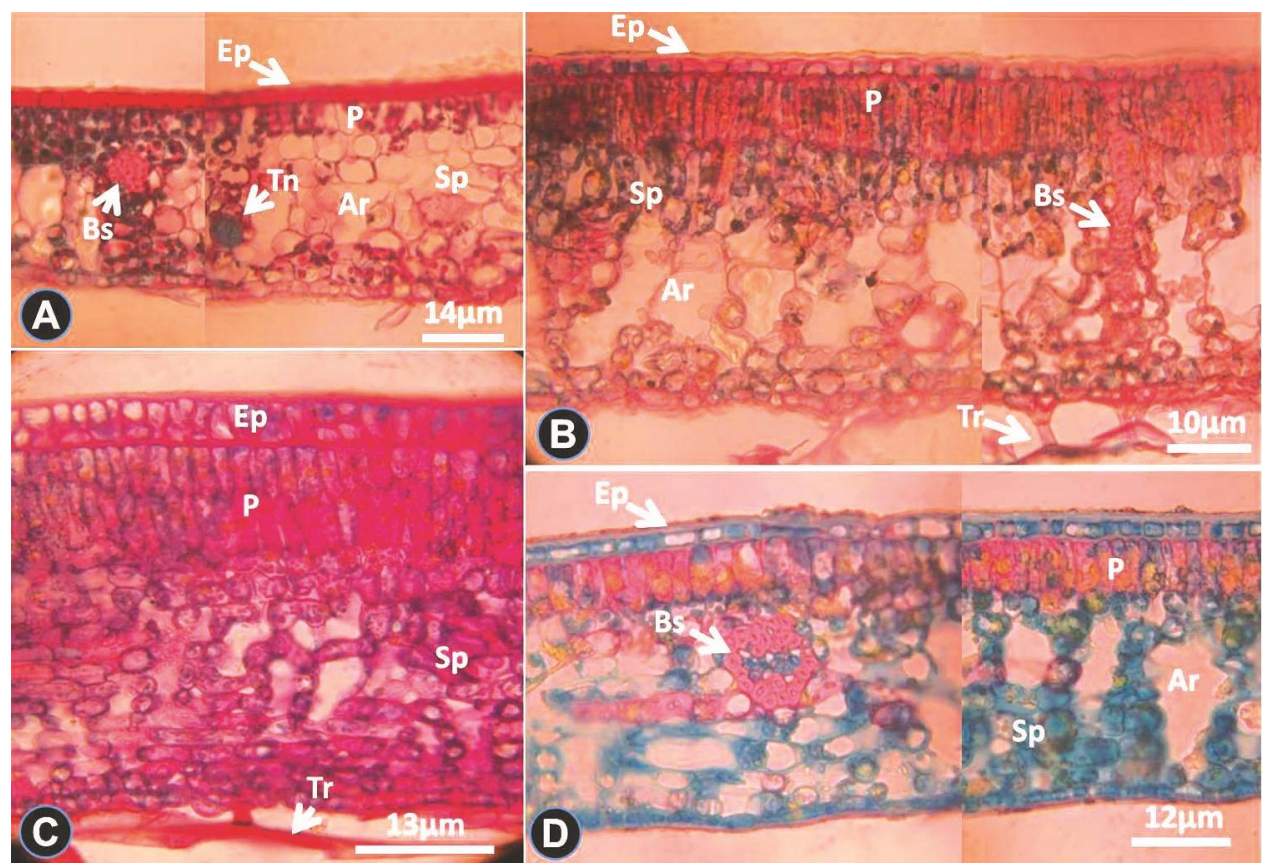

Fig. 2. Leaf lamina of the Chrysophyllum species studied. (A) C. delevoyi, (B) C. albidum, (C) C. cainito, and (D) C. perpulchrum (Ep- epidermis, Bs- bundle sheath, Tr-trichome, Sp- spongy mesophyll, Ar- air space, $\mathrm{P}$ - palisade mesophyll).

Midrib: The midrib is covered with T-shaped trichomes (Figs 3D and 6). The adaxial cuticle has a relatively flat surface (Fig. 6). Calcium oxalate (prismatic crystals) and tanniferous cells were observed in the parenchymatous cortex, pith, and xylem tissues (Fig. 3E and F), and crushed parenchyma in the cortex. The vascular system is arranged in a semi-circular arc with adaxial and central plates, and rib traces on both sides of the arc (Figs 3D and 6). The adaxial cortex has 9-13 layers of cells (13-15 $\mu \mathrm{m}$ thick), and the abaxial cortex 16-18 layers (47-15 $\mu \mathrm{m})$. The ratio of the thickness (abaxial/adaxial) is 3.61 (Table 3).

Petiole: Transverse section (TS) of the petiole has an oval or circular outline with a concave adaxial cuticle and covered by T-shaped non-glandular hairs (Figs 7 and 12E). The vascular bundle has an oval closed system with an abaxial central (modullary) vascular bundle (Fig. 7). The parenchymatous cortex contains calcium oxalate crystals (crystal sands, and prismatic crystals), and tanniferous cells including secretary canals in the cortex, and pith (Fig. 12F and G). Vessels are in radial multiples of 3-9 cells, rays 1-2-celled (Fig. 12H). The adaxial cortex is $95-125 \mu \mathrm{m}$ 
thick (27-32 layers), and the abaxial cortex 127-149 $\mu$ m thick (20-24 layers). The ratio of the abaxial to the adaxial thickness of the cortex is 1.28 (Table 3).

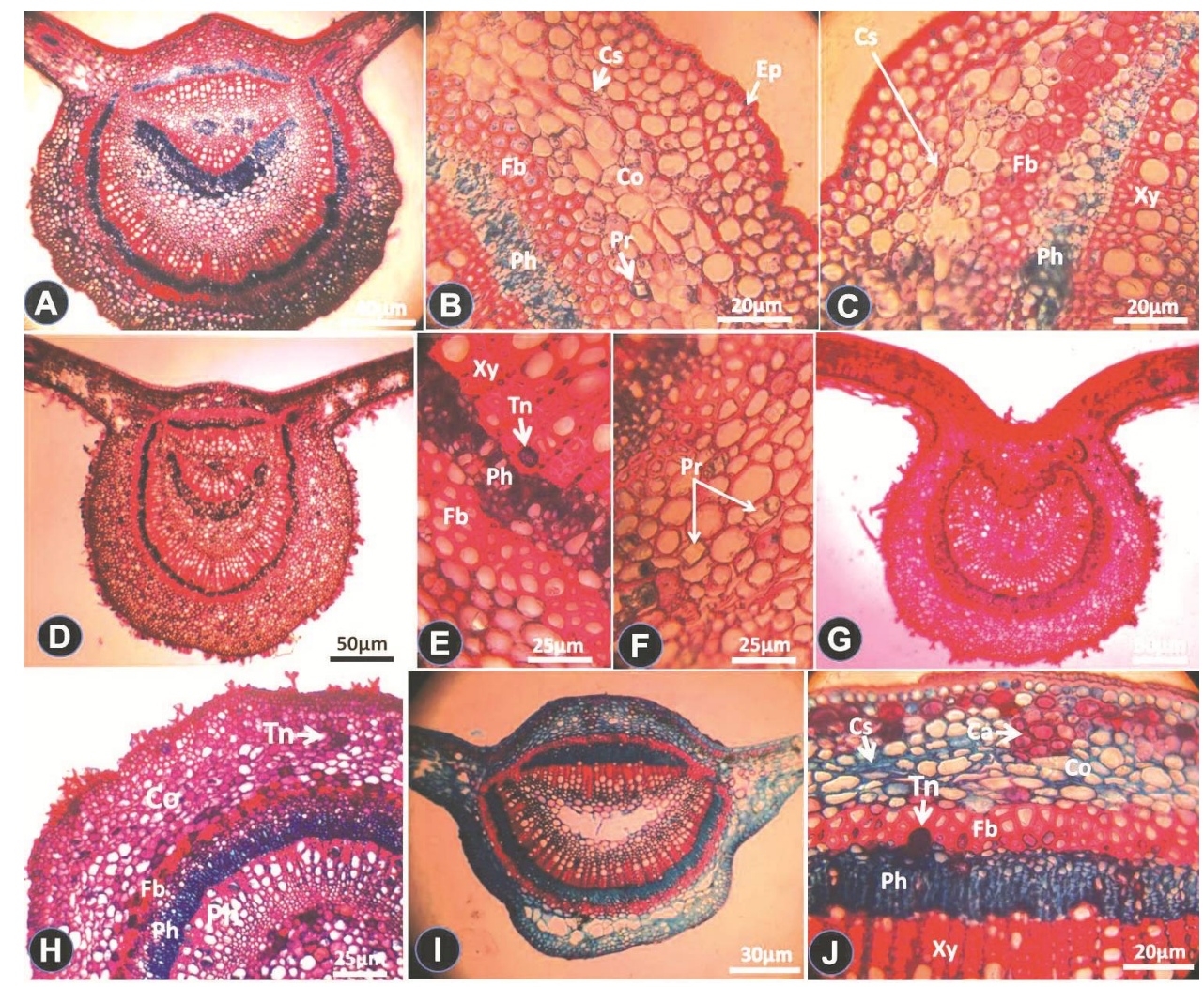

Fig. 3. Midrib TS of Chrysophyllum species studied. A-C $=$ C. delevoyi; D-F $=$ C. albidum, $\mathrm{G}-\mathrm{H}=$ C. cainito, $\mathrm{I}-\mathrm{J}=C$. perpulchrum (Ep- epidermis, $\mathrm{Ph}-$ phloem, Xy- xylem, Ps- prismatic crystal, Ry- ray, Vsvessels, Co- cortex, Cs- crystal sand, Ca- secretory cavity, and Tn- tanniferous cell).

Young stem: Cortex parenchyma is $91-144 \mu \mathrm{m}$ thick with 28-35 layers of cells. The pith parenchyma is $189-214 \mu \mathrm{m}$ thick. The ratio of the pith to cortex thickness is 3.52 (Table 3). Vessels occurred in radial multiples of 2-13 cells, and rays 1-2-celled thick with patches of fiber outwardly, and secretory canals in the cortex (Fig. 13D-G).

\section{C. cainito}

Epidermis: Leaf hypostomatic with an average stomatal index of 20.0. The stomata on the abaxial epidermis are mainly paracytic but rarely anisocytic and tetracytic, and with abnormalities (poorly developed stomata, and contiguous stomata) (Fig. 1G and $1 \mathrm{H}$ ). The adaxial epidermal cells are polygonal to irregular in shape with undulating anticlinal walls while abaxial epidermal cells are polygonal in shape with curved anticlinal walls (Table 2).

Lamina: The lamina has two layers of the abaxial epidermis, and uniseriate adaxial epidermis. The mesophyll is characterized by a 2 layers of palisade parenchyma (11-12 $\mu \mathrm{m}$ thick), and 6-10 layers of spongy parenchyma (20-23 $\mu \mathrm{m}$ thick). The palisade and spongy mesophylls contain tanniferous cells. The spongy parenchyma appeared less regular with large intercellular spaces 
(Fig. 2C). The vascular bundles embedded mainly in the spongy mesophylls and the ratio of the spongy to palisade mesophyll thickness ( $\mathrm{S} / \mathrm{P})$ is 1.89 (Table 2).

Midrib: The midrib outline is circular, and adaxial cuticle is $\mathrm{V}$ to $\mathrm{U}$-shaped or concave. Vascular bundle formed a close system, concave towards the adaxial surface with rib trace, and palisade mesophyll extending to the midrib (Figs 3G and 8). The abaxial surface is covered with simple T-shaped non-glandular trichomes. Cortex, pith, and xylem tissues contain calcium oxalate (sand and prismatic crystals) and tanniferous cells (Fig. 3H), and crushed parenchyma. Adaxial cortex has 3-9 layers of cells (17-13 $\mu \mathrm{m}$ thick) and abaxial cortex 13-19 layers (13-19 $\mu \mathrm{m}$ thick). The ratio of the abaxial to adaxial cortex thickness is 2.18. Vessels are in radial multiples of 3-4 cells, or rarely solitary. Vascular bundles are surrounded outwardly by patches of fiber (Fig. 3H).

Table 2. Leaf anatomical- and epidermal characteristics in Chrysophyllum species studied.

\begin{tabular}{|c|c|c|c|c|}
\hline \multirow{2}{*}{ Plant part } & \multicolumn{4}{|c|}{ Taxa } \\
\hline & C. delevoyi & C. albidum & C. cainito & C. perpulchrum \\
\hline \multicolumn{5}{|l|}{ Lamina } \\
\hline Layer(s) of $\mathrm{Ab}$ and $\mathrm{Ad}$ & 1 & 1 & 2 & 1 \\
\hline Thickness & $21-23 \mu \mathrm{m}$ & $36-38 \mu \mathrm{m}$ & $42-44 \mu \mathrm{m}$ & $33-34 \mu \mathrm{m}$ \\
\hline Palisade mesophyll & $\begin{array}{l}1 \text { layer, } 3-4 \mu \mathrm{m} \\
\text { thick }\end{array}$ & $\begin{array}{l}2 \text { layers, } 12-13 \\
\mu \mathrm{m} \text { thick }\end{array}$ & $\begin{array}{l}2 \text { layers, } 11-12 \mu \mathrm{m} \\
\text { thick }\end{array}$ & $\begin{array}{l}1 \text { layer, } 5-6 \mu \mathrm{m} \\
\text { thick }\end{array}$ \\
\hline Spongy mesophyll & $\begin{array}{l}4-6 \text { layers, } 14- \\
17 \mu \mathrm{m} \text { thick }\end{array}$ & $\begin{array}{l}\text { 4-6 layers, 19- } \\
20 \mu \mathrm{m} \text { thick }\end{array}$ & $\begin{array}{l}6-10 \text { layers, } 20-23 \\
\mu \mathrm{m} \text { thick }\end{array}$ & $\begin{array}{l}\text { 8-9 layers, } \\
23-25 \mu \mathrm{m} \text { thick }\end{array}$ \\
\hline Ratio (S/P) & 5.2 & 1.52 & 1.89 & 4.04 \\
\hline Adaxial epidermis & $2 \mu \mathrm{m}$ thick & $2 \mu \mathrm{m}$ thick & $5-6 \mu \mathrm{m}$ thick & $2-3 \mu \mathrm{m}$ thick \\
\hline Abaxial epidermis & $1-2 \mu \mathrm{m}$ thick & $1-2 \mu \mathrm{m}$ thick & $2-3 \mu \mathrm{m}$ thick & $2-3 \mu \mathrm{m}$ thick \\
\hline \multicolumn{5}{|l|}{ Epidermis } \\
\hline Ad Ep shape & Irregular & Polygonal & Irregular & Irregular \\
\hline Ab Ep shape & Irregular & Polygonal & Irregular & Irregular \\
\hline Hair type & $\begin{array}{l}\text { Unicellular non- } \\
\text { glandular }\end{array}$ & $\begin{array}{l}\text { T-shape non- } \\
\text { glandular }\end{array}$ & $\begin{array}{l}\text { T-shape non- } \\
\text { glandular }\end{array}$ & - \\
\hline Hairs on abaxial surface & + & +++ & + & - \\
\hline Stomata type & $\begin{array}{l}\mathrm{Pa}, \mathrm{Ani}, \mathrm{Te} \text {, and } \\
\text { stomata } \\
\text { abnormalities }\end{array}$ & $\mathrm{Pa}, \mathrm{Te}$ & $\begin{array}{l}\text { Pa, Ani, Te, and } \\
\text { stomata } \\
\text { abnormalities }\end{array}$ & Pa, Ani, Te, Ano \\
\hline $\mathrm{Ab} \mathrm{SI}$ & 9.09 & 23.8 & 20 & 15.38 \\
\hline
\end{tabular}

Note: - = glabrous, $+=$ hairy, $+++=$ highly hairy, $\mathrm{P}=$ Palisade mesophyll thickness, $\mathrm{S}=$ spongy mesophyll thickness, $\mathrm{SI}=$ Stomatal Index, $\mathrm{Ab}=$ abaxial, $\mathrm{Ad}=$ adaxial, $\mathrm{Ep}=$ epidermis, $\mathrm{Pa}=$ paracytic, $\mathrm{Ani}=$ anisocytic, $\mathrm{Te}=$ tetracytic, $\mathrm{Ano}=$ anomocytic .

Petiole: Transverse section (TS) of the petiole has an oval or circular outline with a concave or V-shaped adaxial cuticle (Figs 9 and 12I). The vascular bundle formed a circular closed system and concave adaxially with scanty or unpronounced fiber cells. The parenchymatous cortex contains many calcium oxalate crystals (crystal sands, and prismatic crystals), and tanniferous cells including secretary canals distributed randomly in the cortex, and pith (Fig. 12J-K). Vessels partly in tangential pairs but mainly in radial multiples of 4-10 cells, rays 1-2-celled thick (Fig. 
12L). The adaxial and abaxial cortex has 20-24 layers of cells. Adaxial cortex 60-90 $\mu \mathrm{m}$ thick, and abaxial cortex 82-102 $\mu \mathrm{m}$. The ratio of the abaxial to adaxial cortex thickness is 1.17 (Table 3).

Table 3. Anatomical characteristics of petiole, midrib, and stem of Chrysophyllum species studied.

\begin{tabular}{|c|c|c|c|c|}
\hline \multirow[t]{2}{*}{ Plant part } & \multicolumn{4}{|l|}{ Taxa } \\
\hline & C. delevoyi & C. albidum & C. cainito & C. perpulchrum \\
\hline \multicolumn{5}{|l|}{ Petiole } \\
\hline Ad cortex & $\begin{array}{l}\text { 18-22 layers, } 62-115 \mu \mathrm{m} \\
\text { thick }\end{array}$ & $\begin{array}{l}27-32 \text { layers, } 95-125 \\
\mu \mathrm{m} \text { thick }\end{array}$ & $\begin{array}{l}20-24 \text { layers, } 60-90 \\
\mu \mathrm{m} \text { thick }\end{array}$ & $\begin{array}{l}\text { 11-14 layers, } \\
81-96 \mu \mathrm{m} \text { thick }\end{array}$ \\
\hline Ab cortex & 20-21 layers, $113-138 \mu \mathrm{m}$ & $\begin{array}{l}20-24 \text { layers, } 127- \\
149 \mu \mathrm{m}\end{array}$ & $\begin{array}{l}\text { 20-24 layers, } 82-102 \\
\mu \mathrm{m}\end{array}$ & $\begin{array}{l}\text { 12-15 layers, } \\
50-79 \mu \mathrm{m}\end{array}$ \\
\hline Tannin & + & + & + & + \\
\hline $\mathrm{SC}$ & + & - & +++ & + \\
\hline $\mathrm{Ab} / \mathrm{Ad}$ & 1.34 & 1.28 & 1.17 & 0.68 \\
\hline $\mathrm{Vb}$. & $\begin{array}{l}\text { Close system with adaxial } \\
\& \text { modullary bundles, and } \\
\text { rib traces }\end{array}$ & $\begin{array}{l}\text { Close system with } \\
\text { modullary bundle }\end{array}$ & $\begin{array}{l}\text { Close system with } \\
\text { concave adaxial } \\
\text { surface }\end{array}$ & $\begin{array}{l}\text { Semi-circular } \\
\text { arc with adaxial } \\
\text { plate }\end{array}$ \\
\hline \multicolumn{5}{|l|}{ Midrib } \\
\hline Ad cortex & $\begin{array}{l}\text { 9-11 layers, } 15-18 \mu \mathrm{m} \\
\text { thick. }\end{array}$ & $\begin{array}{l}9-13 \text { layers, } 13-15 \\
\mu \mathrm{m} \text { thick. }\end{array}$ & $\begin{array}{l}3-9 \text { layers, } 17-23 \mu \mathrm{m} \\
\text { thick. }\end{array}$ & $\begin{array}{l}7-8 \text { layers, } 14- \\
22 \mu \mathrm{m} \text { thick. }\end{array}$ \\
\hline $\mathrm{Ab}$ cortex & $\begin{array}{l}8-12 \text { layers, } 23-31 \mu \mathrm{m} \\
\text { thick }\end{array}$ & $\begin{array}{l}\text { 16-18 layers, } 47-51 \\
\mu \mathrm{m} \text { thick }\end{array}$ & $\begin{array}{l}\text { 13-19 layers, } 36-48 \\
\mu \mathrm{m} \text { thick }\end{array}$ & $\begin{array}{l}\text { 4-9 layers, } 14- \\
26 \mu \mathrm{m}\end{array}$ \\
\hline Tannin & + & + & + & + \\
\hline $\mathrm{SC}$ & + & - & +++ & +++ \\
\hline $\mathrm{Ab} / \mathrm{Ad}$ & 1.72 & 3.61 & 2.18 & 0.92 \\
\hline $\mathrm{Vb}$. & $\begin{array}{l}3 / 4 \text { circular with adaxial \& } \\
\text { modullary bundles, and two } \\
\text { interspersed phloem tissues }\end{array}$ & $\begin{array}{l}3 / 4 \text { circular with } \\
\text { adaxial \& modullary } \\
\text { bundles, and rib traces }\end{array}$ & $\begin{array}{l}\text { Close system with rib } \\
\text { trace, and concave } \\
\text { adaxial surface }\end{array}$ & $\begin{array}{l}\text { Close system, } \\
\text { oval in shape }\end{array}$ \\
\hline \multicolumn{5}{|l|}{ Stem } \\
\hline Cortex & $\begin{array}{l}\text { 10-14 layers, } 20-32 \mu \mathrm{m} \\
\text { thick. }\end{array}$ & $\begin{array}{l}28-35 \text { layers, } 91-144 \\
\mu \mathrm{m} \text { thick }\end{array}$ & $\begin{array}{l}\text { 15-18 layers, } 28-47 \\
\mu \mathrm{m} \text { thick }\end{array}$ & $\begin{array}{l}\text { 4-9 layers, } \\
16-20 \mu \mathrm{m} \text { thick }\end{array}$ \\
\hline Pith & $189-214 \mu \mathrm{m}$ thick & $291-411 \mu \mathrm{m}$ thick & $146-162 \mu \mathrm{m}$ thick & $\begin{array}{l}195-217 \mu \mathrm{m} \\
\text { thick }\end{array}$ \\
\hline Tannin & ++ & +++ & +++ & + \\
\hline $\mathrm{SC}$ & - & ++ & + & + \\
\hline $\mathrm{P} / \mathrm{Co}$ & 8.13 & 3.52 & 4.20 & 10.78 \\
\hline
\end{tabular}

Note: $\mathrm{Ad}=$ Adaxial cortex, $\mathrm{Ab}=$ Abaxial cortex, $\mathrm{SC}=$ Secretory canal, $\mathrm{P} / \mathrm{Co}=$ pith thickness $/$ cortex thickness, $\mathrm{Ab} / \mathrm{Ad}=$ abaxial thickness/adaxial thickness.

Young stem: Cortex parenchyma is $91-144 \mu \mathrm{m}$ thick with $28-35$ layers of cells (Fig. 13H-K). The pith parenchyma is $189-214 \mu \mathrm{m}$ thick. The ratio of the pith to cortex thickness is 3.52 (Table $3)$. 


\section{C. perpulchrum}

Epidermis: Leaf amphistomatic with an adaxial average stomatal index of 15.38. The stomata on the abaxial epidermis are mainly paracytic, anomocytic, anisocytic, and tetracytic (Fig. 1I) and the adaxial surface has anisocytic stomata (Fig. 1J). The abaxial surface is hairy while the adaxial epidermis is glabrous. Both adaxial and abaxial epidermal cells are polygonal to irregular in shape, with sinus or wavy anticlinal walls (Table 2).

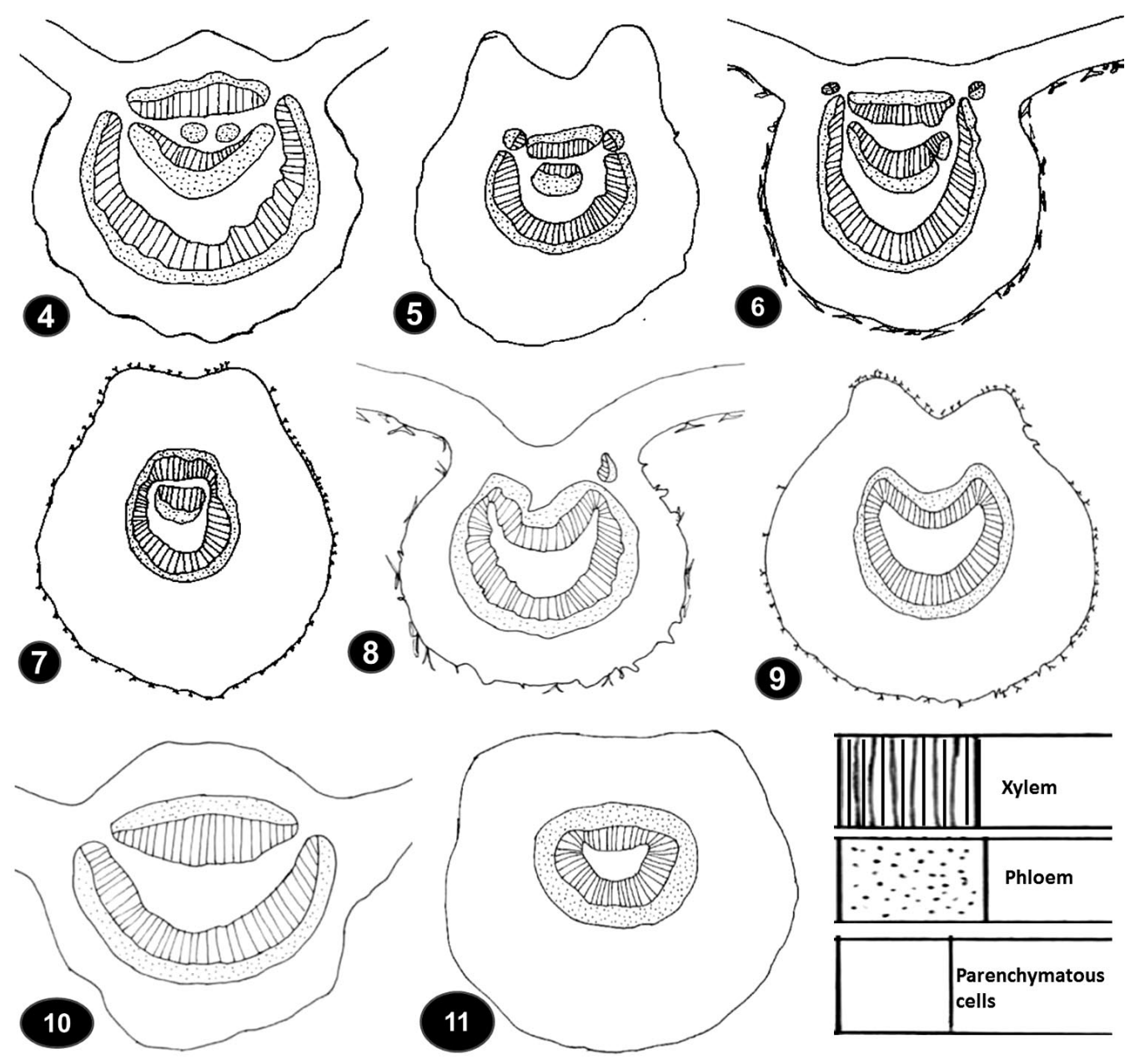

Figs 4-11. Schematic diagram of midrib and petiole showing the vascular bundle arrangements in the Chrysophyllum species studied. 4-5 =C. delevoyi, midrib (4), petiole (5); 6-7 = C. albidum, midrib (6), petiole (7); 8-9 = C. cainito, midrib (8), petiole (9); 10-11 =C. perpulchrum, midrib (10), petiole (11).

Lamina: Lamina is 33-34 $\mu \mathrm{m}$ thick with uniseriate abaxial and adaxial epidermis. The palisade and spongy mesophylls contain tanniferous cells. The palisade tissue consists of a layer of periclinal elongated cells (5-6 $\mu \mathrm{m}$ thick) arranged in rows. The spongy mesophyll has 8-9 layers of cells (23-25 $\mu \mathrm{m}$ thick). The vascular bundles are embedded mainly in the spongy mesophylls and the ratio of the spongy to palisade mesophyll thickness (S/P) is 4.04 (Table 2). 

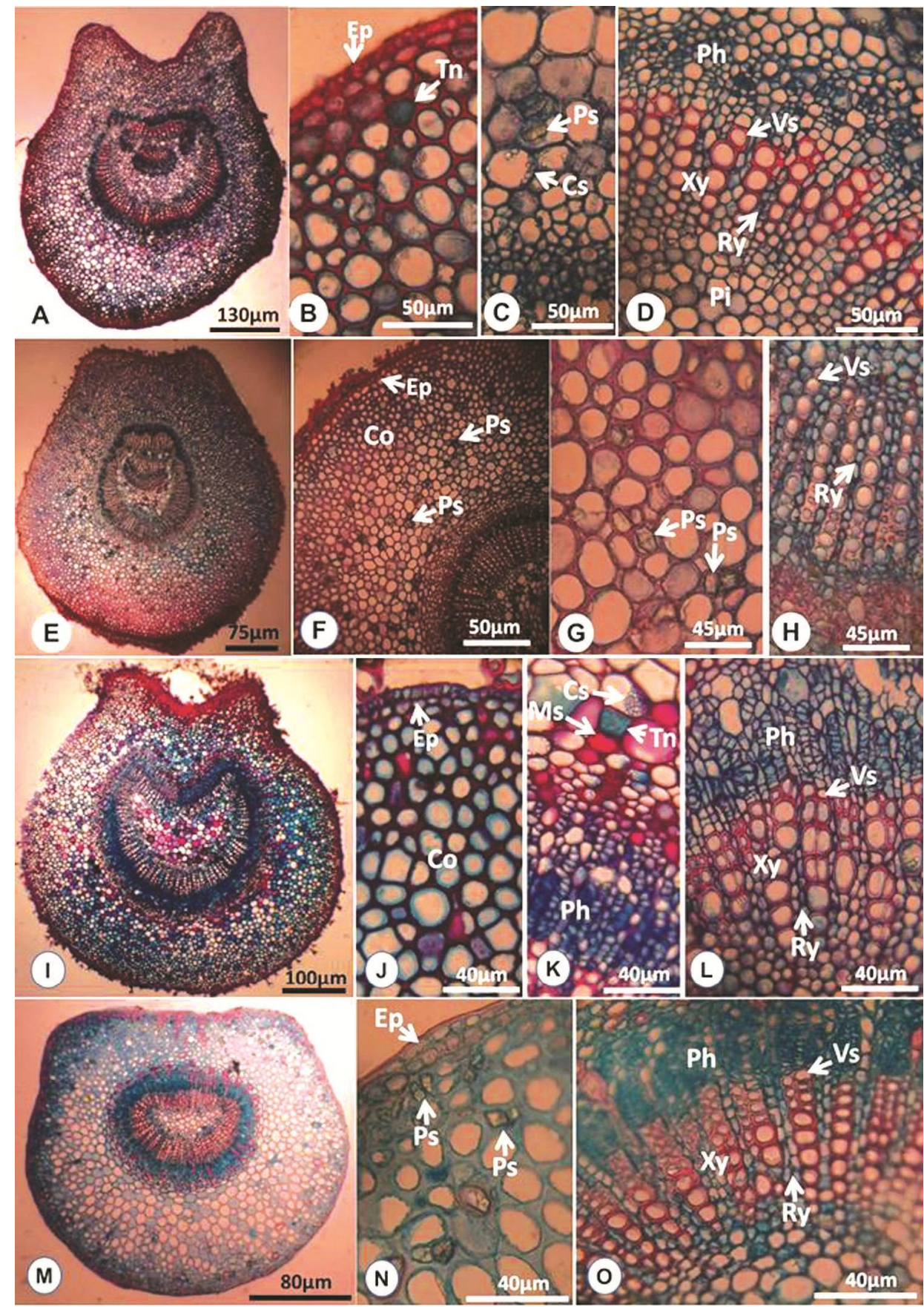

Fig. 12. TS of petiole of Chrysophyllum species. A-D $=$ C. delevoy, $\mathrm{E}-\mathrm{H}=$ C. albidum, $\mathrm{I}-\mathrm{L}=$ C. cainito, $\mathrm{M}-\mathrm{O}$ $=C$. perpulchrum (Ep- epidermis, $\mathrm{Ph}$ - phloem, $\mathrm{Xy}-\mathrm{xylem}, \mathrm{Ps}-$ prismatic crystal, $\mathrm{Ry}-$ ray, Vs- vessels, Co- cortex, Cs- crystal sand, Ms- mucilage, and Tn- tanniferous cell). 


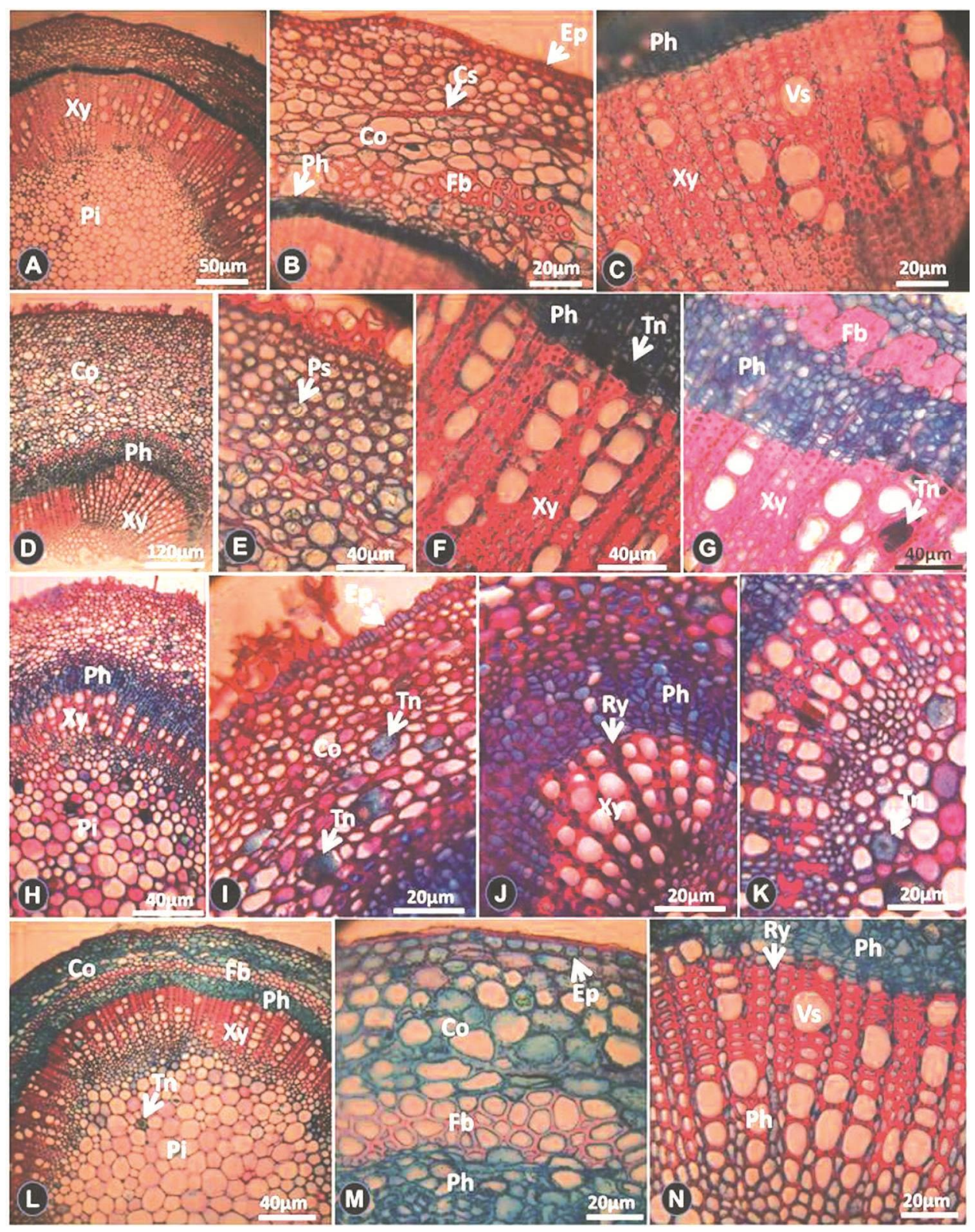

Fig. 13. TS of stem of Chrysophyllum species studied. $\mathrm{A}-\mathrm{C}=C$. delevoyi, $\mathrm{D}-\mathrm{G}=C$. albidum, $\mathrm{H}-\mathrm{K}=C$. cainito, $\mathrm{L}-\mathrm{N}=$ C. perpulchrum (Ep- epidermis, $\mathrm{Ph}-$ phloem, $\mathrm{Xy}-\mathrm{xylem}, \mathrm{Ps}-$ prismatic crystal, $\mathrm{Ry}-$ ray, Vs- vessels, Co- cortex, Col- collenchyma, Pi- pith, C- crushed parenchyma, and $\mathrm{Tn}-$ tanniferous cell).

Midrib: The abaxial and adaxial surfaces are glabrous. The adaxial cuticle formed furrows on both arms of the leaf blade with a convex surface. Calcium oxalate (prismatic crystals) and tanniferous cells are contained in the parenchymatous cortex, pith, and xylem tissues (Fig. 3I and J). The cortex contains crushed parenchyma. The epidermis is uniseriate, the adaxial cortex 
contains 7-8 layers of cells (14-22 $\mu \mathrm{m}$ thick), and abaxial cortex 4-9 layers of cells (14-26 $\mu \mathrm{m}$ thick). The ratio of the thickness of the abaxial to the adaxial cortex is 0.92 (Table 3). The vascular bundles consist of an open semi-circular system with an adaxial plate (Fig. 10). The vessels are in radial multiples of 3-4 cells or partly solitary. Vascular bundle is surrounded outwardly by continuous layer fiber 2-6 cells thick (Fig. 3J).

Petiole: Transverse section (TS) of the petiole showed a circular outline with a flat adaxial cuticle (Figs. 11 and 12M). The vascular bundle formed an oval closed system (Fig. 11). The adaxial parenchymatous cortex has 11-14 layers of cells (81-96 $\mu \mathrm{m}$ thick), while the abaxial parenchymatous cortex has 12-15 layers of cells (50-79 $\mu \mathrm{m}$ thick). Calcium oxalate crystals (crystal sands, and prismatic crystals) are found in the parenchymatous cortex, and pith (Fig. 12N) with few secretory canals. Vessels 1-3 in tangentially or radial multiples of 4-9 cells, and rays are 1-2-celled (Fig. 12O).

Young stem: Transverse section of the stem show scanty secretory canals, solitary vessels, crushed parenchyma, and rays 1-2-celled thick (Figs. 12L-N). Cortex parenchyma is 16-20 $\mu \mathrm{m}$ thick (4-6 layers of cells), and pith parenchyma is $195-217 \mu \mathrm{m}$ thick. The ratio of the pith to cortex thickness is 10.78 (Table 3).

Anatomy of some members of Sapotaceae including Chrysophyllum has been described. Metcalfe and Chalk (1972) recognized laticiferous elements in the leaf mesophyll, cortex, phloem, and pith of stem in the family. Furthermore, they reported the presence of two-armed trichomes of varying arm sizes in some species including ranunculaceous (anomocytic) stomata mainly confined to the abaxial leaf surface or rubiaceous (paracytic). They noted that the woods occur in loose radial or oblique lines and often in multiples of 4 or more cells, rays 1-6-celled wide, but most typically 2-3-celled wide. Mesophyll with one or more cells and spongy with air spaces. Epidermal cells with straight or sinus anticlinal walls, amphistomatic in some members of Chrysophyllum. Crystals solitary, clustered, or in the form of sand. The pericycle of the young stem usually has a discontinuous, but sometimes continuous layer of fiber, xylem forming continuous cylinder is traversed by narrow rays, vessels often in radial rows, solitary crystals always present and abundant in the cortex of all the species of Sapotaceae and sometimes occur in the phloem in Argania Roem. \& Schult., Manilkara Adans., and Mimusops L. and the pith of Madhuca Ham. ex J.F. Gmel., Pouteria Aubl., and Sideroxylon L. Paracytic stomata was observed in all the species studied while anomocytic stomata was recorded in only $C$. delevoyi. Also, $C$. delevoyi and $C$. cainito have the same stomata types but the stomatal index varied significantly among them. Furthermore, the stomatal index among all the species studied varied significantly, which is diagnostic.

We subsequently recorded T-shaped non-glandular trichomes on the lamina, midrib, and petiole of $C$. albidum and $C$. cainito while unicellular non-glandular trichomes in $C$. delevoyi. Also, accessory bundles (rib traces) were seen in the petiole of $C$. delevoyi, and in the midribs of C. albidum and $C$. cainito. The midribs and petioles of $C$. delevoyi and $C$. albidum have central (modullary) and adaxial bundle plates but the midrib of $C$. albidum has rib traces. The nature and arrangement of the vascular bundles could be used to differentiate the species studied. Similarly, Prasawang and Srinual (2020) recorded accessory bundles in C. cainito, and Lima et al. (2019) observed accessory bundles in the petioles of Diploon (Sapotaceae) including many laticifers, prismatic crystals, two-layered palisade parenchyma, and T-shaped trichomes. We observed the abundance of laticifers (mucilages), prismatic crystals, and crystal sand among the Chrysophyllum but the distribution of these cell inclusions was not diagnostic. Prasawang and Srinual (2020) concentrated on the wood, lamina, and petiole anatomical attributes of two Chrysophyllum (C. cainito L. and C. roxburghii G. Don) from Thailand. They found that the shape and outline of the epidermal cell wall, presence or absence of T-shaped trichome, presence or absence of inclusions, 
the shape of the vascular bundle and accessory bundle in the midrib, shape of petiole and vascular bundle, grouping type of vessel, type of axial parenchyma, presence or absence of inclusions in rays, and thickness of fiber walls are diagnostic among the two species studied. In the same way among the species studied, the laticifers occur mainly in the cortical cells, pith cells, xylem, and partly in the phloem and mesophyll cells. The prismatic and sand crystals are found in varying abundance in the cortex and partly in the pith. This result supports the previous findings of Metcalfe and Chalk (1972), Monteiro et al. (2007), Almeida-Jr et al. (2012), Lima et al. (2019), and Prasawang and Srinual (2020) in Chrysophyllum, and other members of Sapotaceae, and in Citrus L. (Ogundare and Saheed, 2012).

Further reference is given by Inyama et al. (2016) who worked primarily on the anatomy of three Chrysophyllum species from Nigeria and concluded that the leaf anatomical features can be useful in delimiting the species. From our study, the species investigated have many similar features such as paracytic stomata, calcium oxalates (crystal sand and prismatic crystals), secretory canals, vessels in radial multiples, and collateral vascular bundles. These anatomical similarities are in line with the findings of Metcalfe and Chalk (1972), Inyama et al. (2016), and Prasawang and Srinual (2020), and affirm the interspecific relationship among the Chrysophyllum studied.

We observed that the lamina of all the four species studied showed uniseriate epidermis except $C$. cainito which has two layers of the adaxial epidermis. Also, all the species were hypostomatic except $C$. perpulchrum. Furthermore, the stomatal index and the ratio of the spongy to palisade mesophyll thickness (S/P) (Table 2), hairiness, the shape of adaxial petiole and midrib outline, number and arrangement of the vascular bundles in the midribs, layers of the adaxial and abaxial cortex in petioles and midribs, stem cortical thickness and layers, stem pith thickness, and pith to cortex $(\mathrm{P} / \mathrm{Co})$ ratio are found to be diagnostic among the species studied (Table 3). Similar observations have been previously reported by Struwig et al. (2011) who showed that the number of chlorenchyma rows may be diagnostic in Boerhavia L. species.

Metcalfe and Chalk (1972), Monteiro et al. (2007), Almeida-Jr et al. (2012), and Prasawang and Srinual (2020) have proved that petiole, wood, and lamina anatomy are of greater taxonomic importance in Sapotaceae. The midrib adaxial cuticle formed furrows on both arms of the leaf blade with an angular or convex outline in C. delevoyi, relatively flat in C. albidum, and convex or arced in $C$. perpulchrum. The vascular bundle in the species studied consists of open semi-circular bundles except in $C$. cainito where it has a closed circular system. On the other hand, the vascular bundles comprised adaxial and central plates with two phloem tissues interspersed between the plates and two rib traces in C. albidum or only an adaxial plate in C. perpulchrum. The petiolar abaxial outlines of all the species are similar but the adaxial outline differed. In $C$. delevoyi and $C$. cainito it is V-shaped while in C. albidum is slightly depressed (concave), and in C. perpulchrum it is flat. The vascular bundle in $C$. delevoyi is distinct forming an $3 / 4$ circle, with adaxial and central plate including two rib traces. The vascular bundles formed a closed modulated system in C. albidum, C. cainato and C. perpulchrum but with central vascular bundle in C. albidum, and concave adaxially in $C$. cainito. The petiole of $C$. perpulchrum and $C$. delevoyi are glabrous but hairy in $C$. albidum and C. cainito. Our results show clear distinguishing midrib and petiolar features and agree that it is of great diagnostic value as stated by Metcalfe and Chalk (1972), Metcalfe and Chalk (1983), Monteiro et al. (2007), Almeida-Jr et al. (2012), and Prasawang and Srinual (2020).

The characteristics of the species such as the stomatal index, the ratio of the spongy to palisade mesophyll thickness, the ratio of cortex thickness, outline, number, and arrangement of the vascular bundles in the midrib, petiole, and young stem are valuable diagnostic features in Chrysophyllum. 


\section{References}

Almeida-Jr, E.B., Araujo, J.S., Santos-Filho, F.S. and Carmen, S.Z. 2012. Leaf morphology and anatomy of Manilkara Adans. (Sapotaceae) from north-eastern Brazil. Plant Syst Evol 299(1): 1-9.

Araújo, J.S., Azevedo, A.A., Silva, L.C. and Meira, R.M.S.A. 2010. Leaf anatomy as an additional taxonomy tool for 16 species of Malpighiaceae found in the Cerrado area (Brazil). Plant Syst Evol 286: 117-131.

Borg, D., Richardson, J.E., Harris, D.J., Gauti, E.R., Hughes, M. and Inder, B.M. 2019. Phylogeny of two African genera of Sapotaceae-Englerophytum and Synsepalum. Edinb. J. Bot. 72(2): 231-267.

Chayamarit, K. 2014. Flora of Thailand. Vol. 11, Part 4. Office of the Forest Herbarium, Department of National Parks, Wildlife and Plant Conservation, Bangkok. ISBN-13 : 978-6163161741.

Das, A., Bin, N.D.B. and Bhaumik, A. 2010. A brief review on Chrysophyllum cainito. IJPI's J Pharmacog Herbal Formul. 1(1): 1-7.

Doan, H.V., Riyajan, S., Iyara, R. and Chudapongse, N. 2018. Antidiabetic activity, glucose uptake stimulation and $\alpha$-glucosidase inhibitory effect of Chrysophyllum cainito L. stem bark extract. BMC Complement Altern Med. 18(1): 267.

Ehsan, M., Ibrar, M., Jelani, G., Khan, S.A. and Hadi, F. 2019. Morpho-anatomical studies of Monotheca buxifolia (Falc.) A. DC. (Sapotaceae). International Journal of Biosciences, 14(3): 299-307.

Ekeke, C. and Agogbua, J.U. 2019. Comparative morphological and anatomical Studies of Boerhavia (Nyctaginaceae) species in Nigeria. Phytologia Balanica, 25(1): 79-88.

Faria, A.D., Pirani, J. R., Ribeiro, J. E. L. S., Nylinder, S., Terra-Araujo, M. H., Vieira, P. P. and Swenson, U. 2017. Towards a natural classification of Sapotaceae subfamily Chrysophylloideae in the Neotropics. Bot. J. Linn, Soc. 185(1): 27-55.

Felippi, M., Grossi, F., Nogueira, A.C. and Kuniyoshi, Y.S. 2008. Fenologia e germinação de sementes de Aguai, Chrysophyllum gonocarpum (Mart. \& Eichl.) Engl. Floresta 38(2): 229-243.

George, O.A., Adenipikun, E.O., Fasogbon, S.A. and Oparanozie, J.A. 2018. Antimicrobial activities of Chrysophyllum albidum leaves, fruits and seeds. Am. J. Med. Sci. 10(1): 28-44.

Gomes, R., Pinheiro, M.C.B. and Lima, H.A. 2008. Fenologia reprodutiva de quatro espécies de Sapotaceae na restinga de Maricá, RJ. Revista Brasil. Bot. 31(4): 679-687.

Govaerts, R., Frodin, D.G. and Pennington, T.D. 2001. World checklist and bibliography of Sapotaceae. R. Bot. Gard. Kew, UK. ISBN: 9781900347945.

Hegde, H., Arathi, A. and Mathew, A. 2016. Evaluation of antidiabetic activity of hydro- alcoholic extract of Chrysophyllum cainito fruits. Int. J. Pharm. 7: 4422-4428.

Howard, R.A. 1979. The petiole. In: Metcalfe, C.R. and Chalk, L. (Eds). Anatomy of the dicotyledons: systematic anatomy of the leaf and stem. Vol. 1. Oxford Claredon, Oxford, pp. 88-96.

Hutchinson, J. and Dalziel, J. M. 1954. Flora of West Tropical Africa. Vol. 1, Part 1, Crown Agents for Oversea Governments and Administrations, London.

Inyama, C.N., Mbagwu, F.N. and Duru, C.M. 2016. Taxonomic Relationship of on Some Chrysophyllum Species based on Anatomic Studies. Med Aromat Plant. 5: 227.

Keay, R.W. 1989. Tree of Nigeria. Oxford Clardon Press.

Koffi, N., Ernest, A.K., Marie-Solange, T., Beugre, K. and Noel, Z.G. 2009. Effect of aqueous extract of Chrysophyllum cainito leaves on the glycaemia of diabetic rabbits. Afr. J. Pharm. Pharmacol. 3(10): 501-506.

Kraus, J.E. and Arduin, M. 1997. Manual ba'sico de me'todos em morfologia vegetal. Editora da Universidade Federal Rural do Rio de Janeiro, Rio de Janeiro.

Li, L.B., Lin, S., Yan, J., Wang, Q.L., Fan, Z.Y., Dong, Q.R., Qin, J.Z. and Xie, Z.G. 2015. Polyphenolic fraction of Chrysophyllum cainito extract induces cell death in osteosarcoma cells. Bangladesh J. Pharmacol. 10(4): 972-979.

Lima, R.G.V.N., Lima, L.F., Ferreira, A.C., Araújo, J.S. and Zickel, C.S. 2019. Leaf Morphoanatomy of Diploon Cronquist (Sapotaceae Juss.) Biota Neotropica. 19(1): e20180600.

Mallikarjun, N., Venugopal, T.M., Suchitha, Y., Swathi, D., Prashith, K.T.R. and Vinayaka, K.S. 2011. Antibacterial activity of Chrysophyllum roxburghii G. Don Gen (Sapotaceae) leaves. Res Rev Biomed Biotechnol. 2(1\&2): 25-27. 
Mao, L.M., Qi, X.W., Hao, J.H., Liu, H.F., Xu, Q.H., Bu, P.L. 2015. In vitro, ex vivo and in vivo antihypertensive activity of Chrysophyllum cainito L. extract. Int. J. Clin. Exp. Med. 8(10): 17912-17921.

Meira, N.A., Klein, L.C., Rocha, L.W., Quintal, Z.M., Monache, F.D., Cechinel, F.V. and Quintão, N.L. 2014. Anti-inflammatory and anti-hypersensitive effects of the crude extract, fractions and triterpenes obtained from Chrysophyllum cainito leaves in mice. J. Ethnopharmacol. 151(2): 975-983.

Metcalfe, C.R. and Chalk, L. 1972. Anatomy of Dicotyledons 2, Clarendon Press. Oxford. pp. 1041-1053.

Metcalfe, C.R. and Chalk, L. 1979. Anatomy of the dicotyledons, vol 1. Systematic anatomy of the leaf and stem, 2nd edn. Oxford Claredon Press, Oxford.

Monteiro, M.H.D.A., Neves, L.J. and Andreata, R.H.P. 2007. Taxonomia e anatomia das espe'cies de Pouteria Aublet (Sapotaceae) do estado do Rio de Janeiro, Brasil. Pesquisas, Bota nica 58: 7-118.

Ningsih, I.Y., Zulaikhah, S., Hidayat, M.A. and Kuswandi, B. 2016. Antioxidant activity of various kenitu (Chrysophyllum cainito L.) leaves extracts from Jember, Indonesia. Agric. Sci. Procedia. 9: 378-385.

Ogundare C.S. and Saheed, S.A. 2012. Foliar epidermal characters and petiole anatomy of four species of citrus 1. (Rutaceae) from south-western nigeria. Bangladesh J. Plant Taxon. 19(1): 25-31.

Parker, I.M., Lopez, I., Petersen, J.J. Anaya, N., Cubilla, R.L. and Potter, D. 2010. Domestication syndrome in caimito (Chrysophyllum cainito L.): Fruit and seed characteristics. Econ. Bot. 64(2): 161-175.

Pennington, T. D. 1991. The Genera of Sapotaceae. Royal Botanic Gardens, Kew.

Petersen, J.J., Parker, I.M. and Potter, D. 2012. Origin and close relatives of a semi-domasticated neotropical fruit tree: Chrysophyllum cainito (Sapotaceae). Am. J. Bot. 99(3): 585-604.

Prasawang, S. and Srinual, A. 2020. Comparative leaf and wood anatomical characteristics of Chrysophyllum (Sapotaceae) relate to taxonomy of the species in Thailand. Biodiversitas 21: 1578-1587.

Reis, L.P., Silva, J.N.M., Reis, P.C.M., Carvalho, J.O.P., Queiroz, W.T. and Ruschel, A.R. 2013. Efeito da exploração de impacto reduzido em algumas espécies de Sapotaceae no leste da Amazônia. Floresta, 43(3): 395-406.

Shailajan, S. and Gurjar, D. 2014. Pharmacognostic and phytochemical evaluation of Chrysophyllum cainito Linn. leaves. Int J Pharm Sci Rev. Res. 26(1): 106-111.

Struwig, M., Jordan, A. and Siebert, S.J. 2011. Anatomy of the southern African Boerhavia and Commicarpus species (Nyctaginaceae). Bangladesh J. Plant Taxon. 18(2): 105-115.

Swenson, U., Nylander, J.A.A. and Munzinger, J. 2018. Phylogeny, species delimitation and revision of Pleioluma (Sapotaceae) in New Caledonia, a frequently gynodioecious genus. Aust. Syst. Bot. 31(2): 120-160.

Swenson, U., Nylinder, S. and Munzinger, J. 2013. Towards a natural classification of Sapotaceae subfamily Chrysophylloideae in Oceania and Southeast Asia based on nuclear sequence data. Taxon, 62(4): 746-770. 